\title{
Dendrochronological study of the Sawicki landslide activity in the Beskid Niski Mts (Polish Flysch Carpathians)
}

\author{
Krzysztof Kiszka* \\ Szymbark Research Station, Department of Geoenvironmental Research, Institute of Geography and Spatial Organization, Polish \\ Academy of Sciences, Kraków, Poland, *kiszkak@zg.pan.krakow.pl
}

\begin{abstract}
The article presents the results of the dendrogeomorphological study of the activity of the Sawicki landslide, located in the Beskid Niski Mts (Polish Flysch Carpathians). The study was conducted within two study sites in the lower part of the landslide. The landslide movements were dated using the dendrogeomorphological method, basing on the eccentricity indicators calculated for the two coniferous species, i.e. Scots pine (Pinus sylvestris) and silver fir (Abies alba). It was found landslide activity in years: 1899, 1901, 1905, 1910, 1913-1914, 1920-1921, 1929-1931, 1935, 1937, 1945, 1977, 1979, 1981, 1984-1985, 1990, 1992-1993, 1997, 2003-2004, 2006, 2010-2012. The greatest activity was characterized for the northern part of the study site B and the south-western slopes of the Szklarki stream valley (study site A). Studies have shown only a partial dependence between precipitation and landslide episodes. The data were confronted with the results of dendrogeomorphological studies, conducted in the northern and central parts of the landslide. The results demonstrate the significant complexity of mass movements within large-area landslide.
\end{abstract}

Key words: dendrogeomorphology, mass movement, landslide activity, the Sawicki landslide, eccentricity of tree rings, Beskid Niski Mountains

\section{Introduction}

The destructive activity of landslides is the primary threat in Polish Flysch Carpathians (Rączkowski 2004, Chowaniec et al. 2012). Dendrogeomorphology is one of the methods commonly used in recent years in the study of the process of land sliding (Zielski, Krąpiec 2004). The dendrogeomorphological methods involve dating mass movements that have been recorded in the annual rings of trees growing within landslides. Mass movements are causing a change in the trees position - mostly tree trunks are deflected relative to the previous position. Trees subjected to stress due to mass-movements have manifested strong and sudden decreases in ring growth (Shroder 1975, 1980, Fantucci, McCord 1995, Schweingruber 1996, Stoffel, Perret 2006, Zielonka, Dubaj 2009, Corona et al. 2014, Šilhán, Stoffel 2015). As a response to gravity, where the cambial cells are orientated other than vertically, the compression wood is formed instead of normal wood (Winchester et al. 2007). The tree rings system becomes asymmetrical, and the first ring showing eccentricity can reliably provide a date for landslide movements.

The pioneers of the dendrogeomorphology method are Alestalo (1971), Shroder (1975), Butler (1979), while Bednarz (1986) and Margielewski (1997) were the first one to conduct such research in Poland. Many landslide episodes were dated on the basis of dendrochronological measurements, both within the Western Carpathians (Krąpiec, Margielewski 2000, Wistuba et al. 2013, Šilhán 2012, 2016) and in the Sudetes (Malik, Owczarek 2005, Wistuba et al. 2012, Migoń et al. 2014). The dendrogeomorphology method also allows for dating other processes: debris flow (Malik, Owczarek 2009, Šilhán et al. 2015), bank erosion (Milik, Matyja 2008), gully erosion (Malik 2008), rockfall (Stoffel, Perret 2006, Zielonka, Dubaj 2009), root erosion (Malik, Owczarek 2005, Buchwał, Wrońska-Wałach 2008), flooding (Wistuba 2008, Ballesteros-Canovas et al. 2015), volcanology (Bollschweiler et al. 2010, Franco-Ramos et al. 2013).

Large landslides are characterized by uneven spatial diversity of movements. There are very unstable 
areas, characterized by multiple mass movements, and also areas of more stable, which are moved less often. The main aim of the study is to determine the years of activity and spatial variability of movements within the Sawicki landslide based on dendrogeomorphological methods. Similar researches were conducted by Fantucci and McCord (1995) in Viterbo province (central Italy). Basing on the cores of oaks (Quercus cerris) they have designated active and stable zones within the landslide. Lopez Saez et al. (2014) drew attention to the different surface of mass movement areas in different years within the Davids-Bas landslide in French Alps. Also Margielewski (1997) indicated for some landslides in the Beskid Sądecki Mts the most active areas using dendrogeomorphological method. It uses of dated tree-ring series to find the landslide events.

\section{Study area}

The Sawicki landslide, named after the first scientist who analysed this landslide in 1913 (Sawicki 1917), formerly known as the Szklarki landslide (named after the surrounding), is located in Szymbark near Gorlice. It is situated within the southern slopes of the Maślana Góra hill (753 m a.s.l.), on the northern rim of Beskid Niski Mts (the Polish Flysch Carpathians) (Fig. 1). Maślana Góra hill is a longitudinal range of insular type. Its ridge is characterized by an undulating profile with numerous small passes and domed tops with height differences up to $20 \mathrm{~m}$. Average slope of the ridge is $3-4^{\circ}$, up to $10^{\circ}$. Southern slopes, descending to the Ropa river valley are characterized by a large length and a steep incline from $23^{\circ}$ to $40^{\circ}$ and convex profile. Slopes are strongly transformed by large landslides and deep V-shaped valleys, which are cut into bedrock. The northern part of the massif is subject to only minor transformations, including headwaters.

The Maślana Góra hill is formed by flysch of the Magura Nappe, which is composed of glauconitic sandstones, Ciężkowice sandstones, shales (variegated, red and green), marls and conglomerates. The slope covers are skeletal with coarse fraction ranges from $20-40 \%$ on shale layers to $50-95 \%$ on sandstone rocks. They are mainly loamy or argillo-loamy slope covers with different physical and chemical characteristics, mainly related to the type of bedrock. Covers are mainly medium clay (Gil 1979).

The acid brown soils and leached brown soils are dominating. The areas occupied by landslides are covered by plastosols - clay-loam soils on weathered shale complexes. The high content of clay particles affects the excessive moisture, high brevity and very poor permeability.

About $60 \%$ of the area is located in the warm temperate climate zone (average annual temperature exceeds $5^{\circ} \mathrm{C}$ ), while the rest is situated within a temperate cool climate (average annual temperature is less than $5^{\circ} \mathrm{C}$ ). The border between the zones runs along the $600 \mathrm{~m}$ a.s.l. isohypse. The mean annual air temperature (based on data of the IG\&SO PAS Research Station for the period $1968-2015)$ is $8.0^{\circ} \mathrm{C}$. The mean annual precipitation is $833 \mathrm{~mm}$ (from 535 $\mathrm{mm}$ in 1982 to $1164 \mathrm{~mm}$ in 1974). The highest precipitation occurs in June (124 $\mathrm{mm}$ in average) and the lowest, only $36 \mathrm{~mm}$, in February. The highest monthly precipitation was recorded in July 2011 (325 mm), while the highest daily precipitation in 30 June 1973 was $125 \mathrm{~mm}$. The lowest monthly amount of precipitation was recorded in February 1976 (only $0.5 \mathrm{~mm}$ ).

The vast majority of study area is located within the lower forest zone. The largest part of the area is covered by the Carpathian beech forest (Dentario glandulosae - Fagetum), which is rising above the height of $500 \mathrm{~m}$ a.s.l. It consists mainly of common beech (Fagus sylvatica) (Gil 1994). The ridge and upper parts of the slopes are covered with small patches of sycamore forest (Phyllitido-Aceretum). Slightly lower occurs the fir forest with black raspberry (Rubus hirtus - Abies alba), which consists mainly of silver fir (Abies alba) with a touch of pedunculate oak (Quercus robur) and Scots pine (Pinus sylvestris), rarely sycamore (Acer pseudoplatanus) and common beech (Fagus sylvatica) (Gil 1979). Marshy slopes of gleyic soils are wooded by and alder swamp forest (Caltho-Alnetum). Below an altitude of $500 \mathrm{~m}$ a.s.l., mainly on the southern slopes there is hornbeam-oak forest (Tilio-Carpinetum), which is typical for foothill floor forest. There is the forest of common hornbeam (Carpinus betulus) and pedunculate oak (Quercus robur) with admixtures of little-leaf linden (Tilia cordata), common ash (Fraxinus excelsior), sycamore (Acer pseudoplatanus), common beech (Fagus sylvatica), wild cherry (Prunus avium) and comon aspen (Populus tremula). Along the river and stream valleys grow trees included the Carpathian alder forest (Alnetum incanae), which is consist mostly of grey alder (Alnus incana) mixed with white willow (Salix alba), common ash, sycamore and common hornbeam. Over $70 \%$ of the area of the Sawicki landslide is covered with forest.

The Sawicki landslide is one of the largest in the Polish Carpathian with an area of $1.62 \mathrm{~km}^{2}$ and the volume of the material displaced of about $25 \mathrm{mln} \mathrm{m}^{3}$. This is an active, detrusive complex landslide. It was formed in the Holocene and underwent cyclic renewal as a result of heavy rainfall (Racczkowski, Zabuski 2008).

The landslide is characterized by an elongated shape, narrowing down the slope (Fig. 1). It extends over a length of 2850 meters (average width of approx. $550 \mathrm{~m}$ ), the upper niche is at an altitude of 725 $\mathrm{m}$ a.s.l. while the face is at an altitude of $340 \mathrm{~m}$ a.s.l. (difference in height is $385 \mathrm{~m}$ ). 


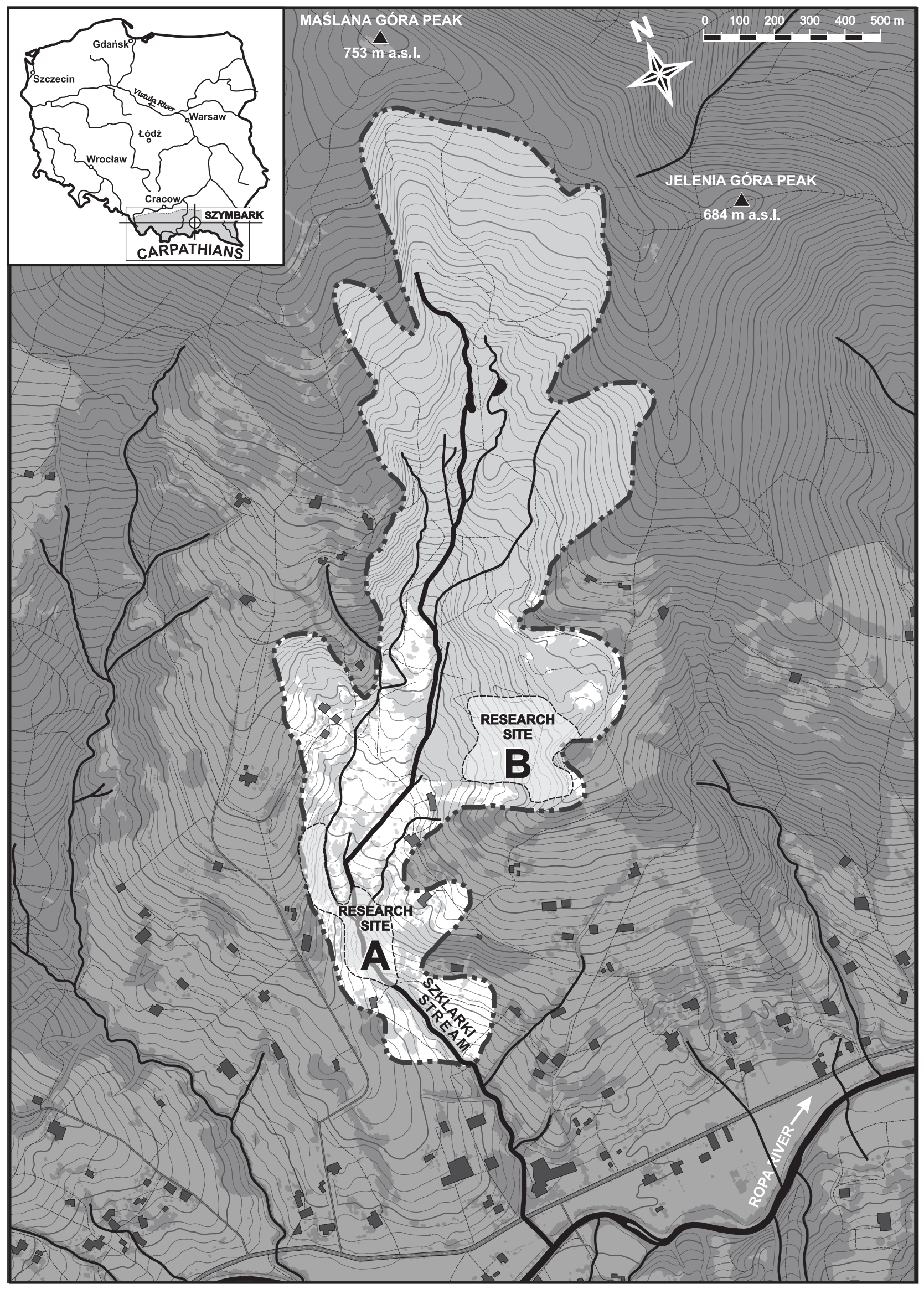

Fig. 1. Location of the studied Sawicki landslide in Beskid Niski Mts (the Polish Flysch Carpathians) 


\section{Study sites}

Within the Sawicki landslide two research sites were established (Fig. 2) for evaluating differentiation of landslide dynamic. The research site $\mathbf{A}$ was located in the lower part of the landslide and included 60 trees samples, mostly Scots pine (Fig. 3). The studied trees were concentrated in three major groups, two of them located on the western slopes of valley (about $170 \mathrm{~m}$ above the Szklarka stream) and in the third group, less numerous and more dispersed (eastern slope of the valley).

The research site B covered only eastern slopes of the Szklarka stream valley and was located in the central part of the landslide. Among 125 trees studied within this plot $70 \%$ were represented by silver fir (Fig. 3).

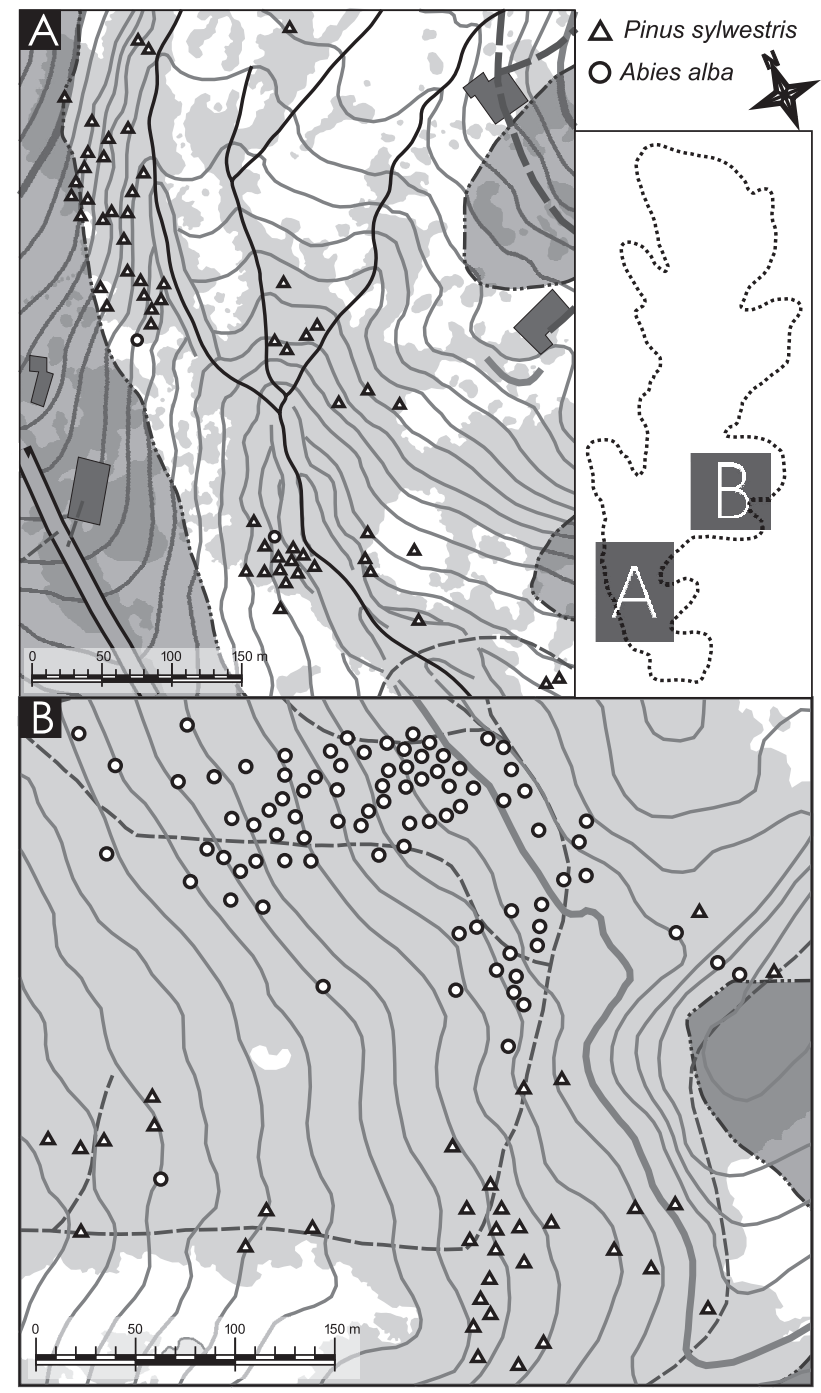

Fig. 2. Location of sampled trees within detailed research site A and B, situated within the Sawicki landslide in Beskid Niski Mts

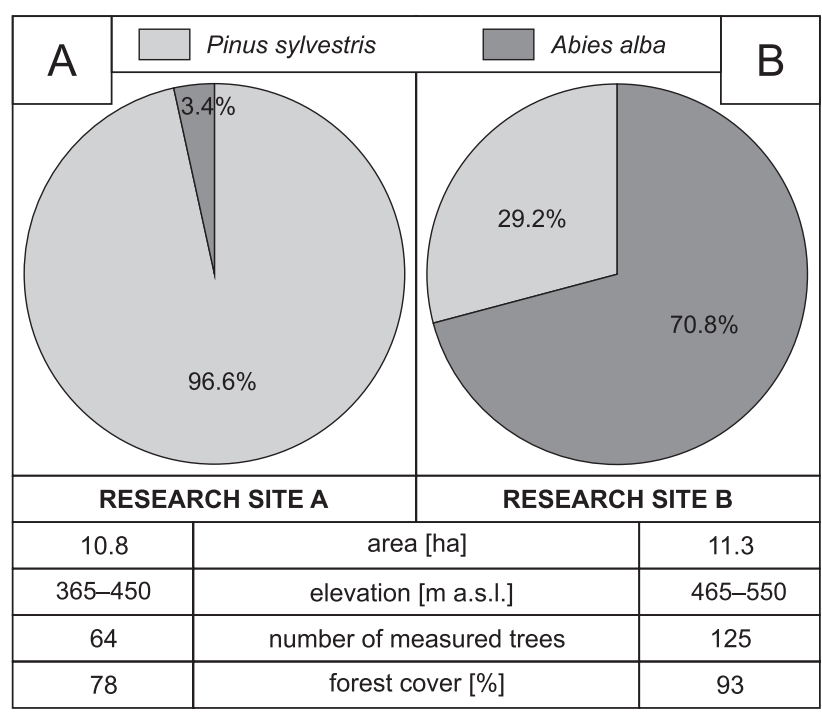

Fig. 3. Characteristics of the research sites A and B within the Sawicki landslide in Beskid Niski Mts

\section{Materials and methods}

\section{Field sampling}

Assessment of the Sawicki landslide activity was performed using the dendrogeomorphological method. In the years 2013-2014, using an increment borer, cores were taken from two coniferous species - Scots pine (Pinus sylvestris) and silver fir (Abies alba), growing in the lower and middle parts of the Sawicki Landslide (Fig. 2). Cores were taken both from an upslope and downslope side of each stem in one axis at the diameter at breast height (DBH). In the next step cores were dried and prepared for microscopic analysis by polishing using angle grinder and sandpaper of varying granularity: from P24 to P400. Then, using a special DENDROLAB microscope and TELLERVO Software, the width of tree rings was measured to an accuracy of $0.1 \mathrm{~mm}$, on the basis of which growth curves were plotted. The eccentricity indexes were calculated on the basis of the differences between the upslope and downslope growth curves (Wistuba et al. 2013). The yearly variation of eccentricity indexes was further used for dating the activation of landslide fragments.

\section{Age of the trees and basic stem parameters}

During fieldwork, sampling of 93 trees of Scots pine (Pinus sylvestris) and 96 trees of silver fir (Abies alba) was carried out (Table 1). Pine trees were young. The mean age was 57 years, and varied from 29 years to 89 years. The mean age of the fir trees was 87 years and it was only two years less than the oldest pine sampled. The oldest Abies alba tree was a fir which began to grow before 1890 (124 years). The youngest fir was 36 years. 
Table 1. The descriptive characteristics of sampled trees within the Sawicki landslide

\begin{tabular}{|c|c|c|c|c|c|c|c|}
\hline \multirow{2}{*}{ Tree species } & \multirow{2}{*}{$\begin{array}{l}\text { Num- } \\
\text { ber of } \\
\text { trees }\end{array}$} & \multicolumn{3}{|c|}{$\begin{array}{l}\text { Age of the } \\
\text { trees } \\
\text { [years] }\end{array}$} & \multicolumn{3}{|c|}{$\begin{array}{l}\text { Tree diameter } \\
\text { at breast height } \\
\mathrm{DBH}[\mathrm{cm}]\end{array}$} \\
\hline & & $\min$ & $\begin{array}{l}\text { ave- } \\
\text { rage }\end{array}$ & $\max$ & $\min$ & $\begin{array}{l}\text { ave- } \\
\text { rage }\end{array}$ & $\max$ \\
\hline Pinus sylvestris & 93 & 29 & 57 & 89 & 28 & 46 & 64 \\
\hline Abies alba & 96 & 36 & 87 & 124 & 22 & 45 & 77 \\
\hline
\end{tabular}

The average size of DBH for both species was very similar and equaled $45-46 \mathrm{~cm}$, although the $\mathrm{DBH}$ of the fir trees was characterized by greater diversity. The height of studied trees ranged from 20 to 35 meters.

\section{Dendrochronological analysis}

For each tree two dendrochronological curves were plotted (for the upslope and downslope side of the stem) in basing on a tree rings width. The cross-dating procedure was used. Absolute dendrochronological scale was formed with the growth curves calibrated by using characteristics years and years with abrupt growth changes (Zielski, Krąpiec 2004). The dendrochronological curves were also calibrated with site chronology standards curves, made for local trees by Szychowska-Krąpiec (2000). Then the following were calculated: eccentricity (the difference in the width of the upslope and downslope increments), eccentricity index (the ratio of deconcentricity and the width of annual growth, expressed as a percentage) and the yearly variation of the eccentricity index (the index difference between the reference year and the previous year) on the basis of formulas proposed by Wistuba and Malik (Wistuba, Malik 2011, Wistuba et al. 2012, Wistuba et al. 2013):

$$
\begin{gathered}
E x=U \times-D x \\
\text { Ei } x=(E \times / D \times) \times 100 \%(\text { if } D>U) \\
\text { Ei } x=(E \times / U \times) \times 100 \%(\text { if } D<U) \\
\text { vEi } x=\text { Ei x }- \text { Ei x-1 }
\end{gathered}
$$

where:

E - eccentricity [mm],

Ei - eccentricity index [\%],

$\mathrm{vEi}$ - yearly variation of the eccentricity index [\%],

$\mathrm{U}$ - width of tree ring on the upslope side of tree trunk $[\mathrm{mm}]$,

$\mathrm{D}$ - width of tree ring on the downslope side of tree trunk [mm],

$\mathrm{x}-$ year/annual tree ring.

The cores of silver fir and Scots pine trees were also collected from the reference site within a stable slope, located in the vicinity of the landslide. Samples from 10 pines and 12 firs were used for construct a local site chronology of control site for both species. Based on the tree rings width, an eccentricity indexes, the arithmetic mean and standard deviation of the annual variation of eccentricity index were calculated. According to dendrogeomorphological method (Wistuba, Malik 2011), the arithmetic mean and standard deviation were summed up. The results define mass movements' thresholds for the studied tree species:

- scots pine has adopted a high probability of mass movements at the values of the yearly variation of eccentricity index greater than $29.9 \%$ or less than $-30.55 \%$;

- silver fir has adopted a high probability of mass movements at the values of the yearly variation of eccentricity index greater than $34.0 \%$ or less than $-34.94 \%$.

The years in which more than $10 \%$ of trees exceeded defined mass movements thresholds, have been considered as periods of landslide activity.

\section{Precipitation data}

Results of landslide activity were correlated with amount of precipitation. The precipitation records are measured since 1968 at the Research Station in Szymbark (Institute of Geography and Spatial Organization - Polish Academy of Science), located approx. 4 $\mathrm{km}$ (in a straight line) away from the Sawicki landslide. Data are presented as the total rainfall for the periods: calendar year (January-December), hydrological year (November-October), growing season (May-October) and the dormant season (November-April), winter (December-February), spring (March-May), summer (June-August), autumn (September-November). Annual and seasonal precipitations were compared with the number of rainy days in the specified seasons.

In the article the results of Twardosz and Cebulska study (2014) were used, who have designated a months of abnormally high monthly precipitation, based on data from the Carpathians meteorological stations. For the attitude of the emergence of anomalously high sums of monthly precipitation, the authors adopted the upper quartile, increased by 1.5 times of the interquartile range. Data from meteorological stations in Dukla, Jasło, Krynica, Nowy Sącz, and Tarnów were used (Twardosz, Cebulska 2014).

\section{Previous dendrogeomorphological studies within the Sawicki landslide}

The results of the dendrogeomorphological study were discussed on background of former dendrochronological data from the study area. The dendrochronological analysis of the landslide areas in the Beskid Niski Mountains were conducted in 20012004 (Krąpiec et al. 2004). The dendrogeomorpho- 
logical method has been applied as an alternative and secondary form of landslides monitoring for the standard measurements used by the Polish Geological Survey (Krąpiec et al. 2008). Landslide episodes in that study were determined on the basis of the correlation and visual comparisons of dendrochronological curves established for the trees affected by the landslide with the reference site chronology. The cores were taken from the northern and central parts of the Sawicki landslide. A total of 129 sampled were collected including silver fir, Scots pine, European larch, Norway spruce and sycamore.

In 2011-2012 Nawrocka (2013) conducted dendrochronological research on the Sawicki landslide. Based on her study periods of landslide activity were determined on the basis of the rate of annual volatility of the eccentricity index (Wistuba, Malik 2011). Similarly, as in the case of previous studies (Krąpiec et al. 2004), the cores were taken from the northern and central parts of the Sawicki landslide, with the difference that the samples were characterized by a greater uniformity of space distribution. Increment cores were taken from 63 conifers (Scots pine, silver fir, European larch), of which only 33 trees grew within the landslide area.

\section{Results}

Reconstruction of the Sawicki landslide activity

Based on dendrochronological analyses of Scots pine and silver fir events of Sawicki landslide activity were established. The greatest number of landslide movements, assessed by yearly variation of the eccentricity index took place in the following years: 1899 ,
1901, 1905, 1910, 1913-1914, 1920-1921, 1929-1931, 1935, 1937, 1945, 1977, 1979, 1981, 1984-1985, 1990, 1992-1993, 1997, 2003-2004, 2006, 2010-2012 (Fig. 4). The whole analyzed period since 1890 can be divided into three cycles. The first period $(1885-1945)$ was characterized by a high frequency of activation of landslide movements that appeared regularly, i.e. approximately every $5-6$ years. Whereas in the second period (1946-1976) evidences of landslides activity were recorded only in a small number of trees, i.e. (below $10 \%$ of studied population. Finally, the third period (1977-2012) was characterized by the largest number (from five in 1999 to 25 in 2010 and 29 in 1993) of landslide episodes recorded in the growth rings of the studied trees.

Analysing the eccentricity indexes for Scots pine (Pinus sylvestris), periods of landslide activity were specified into: 1936-1939, 1945, 1959, 1962, 1978 1979, 1981-1982, 1984-1985, 1990, 1992-1993, 1998, 2003-2004, 2006-2007, 2010-2012 (Fig. 5). Within the period of 77 years a total of 24 events years were detected in pines during which activations of landslides movement possibly took place. The comparable period of landslide activity assessment for silver fir (Abies alba) was much longer and covered 114 years. Throughout that time the largest number of landslide episodes was recorded in the rings of fir in periods: 1899-1901, 1903, 1905, 1910, 1913-1914, 1920-1921, 1929-1932, 1935, 1937, 1945, 1977, 1981-1985, 1990, 1992-1993, 1997-1998, 2003-2004, 2006, 20102012. Landslide processes occurred in the total of 34 years out of the period of 114 years (Fig. 5).

\section{The dynamics of landslide movements}

The periods of landslide activity within the research site A included the years: 1945, 1947, 1953, 1955,

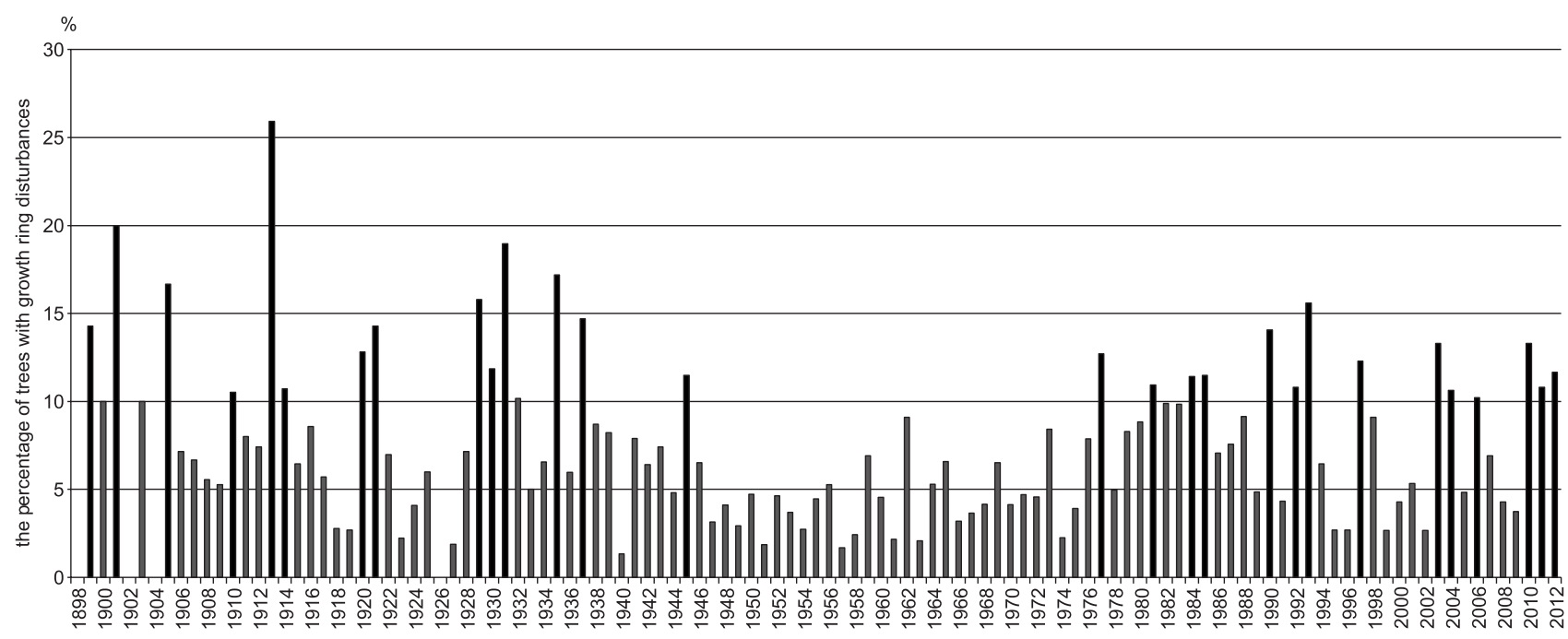

Fig. 4. Years with the largest number of growth ring disturbances indicating landslide movement (dark bars), selected on the basis of the rate of yearly variation of the eccentricity index for all trees 
the rate of annual volatility of the deconcentricity index for Pinus sylvestris trees

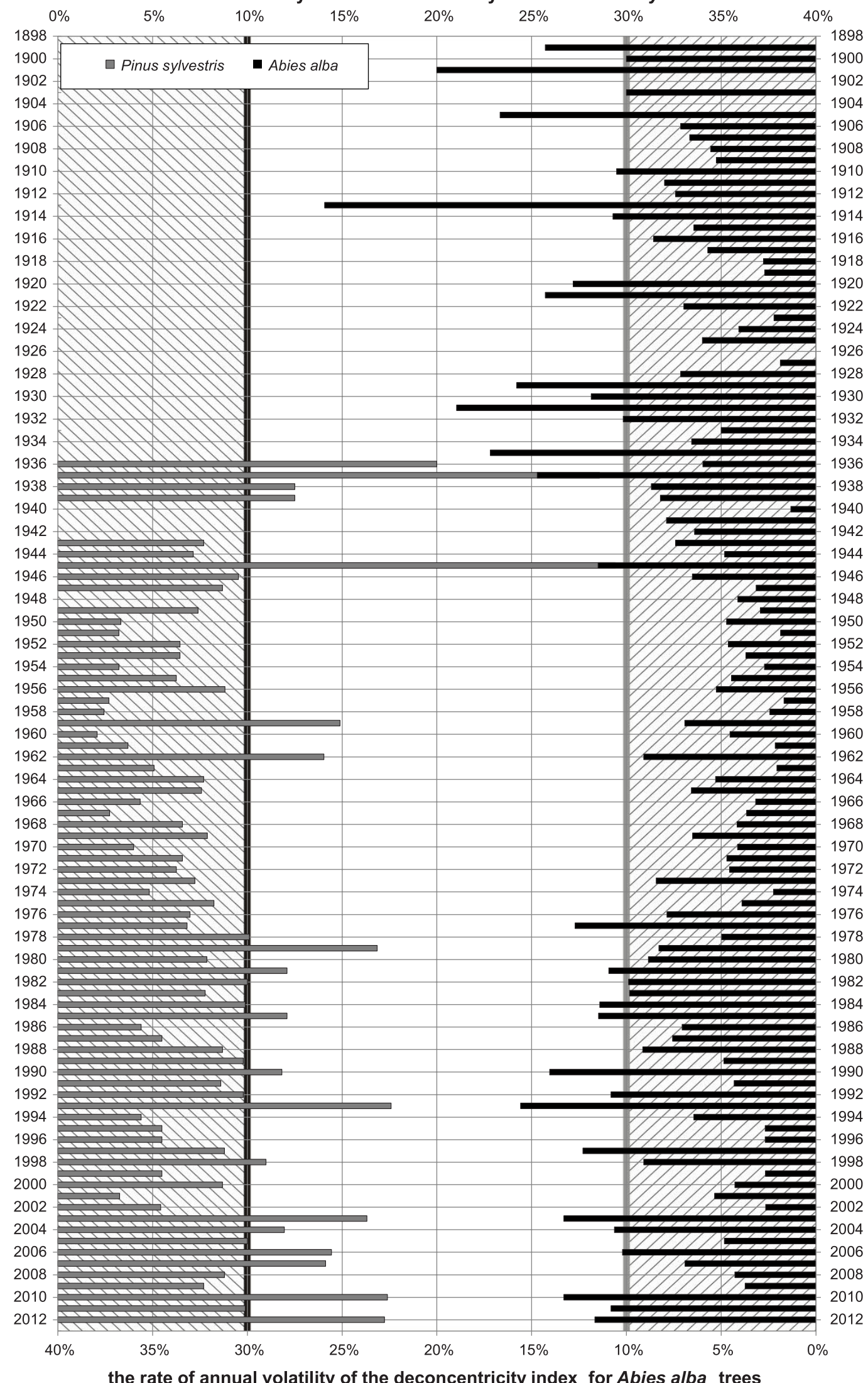

the rate of annual volatility of the deconcentricity index for Abies alba trees

Fig. 5. The frequency of landslide signals, established on the basis of the rate of yearly variation of the eccentricity index for Scots pine (Pinus sylvestris) and silver fir (Abies alba) studied within the Sawicki landslide in Beskid Niski Mts (the Polish Flysch Carpathians) 
1959, 1962, 1968-1970, 1971-1972, 1975-1979, 19811984, 1988-1990, 1993, 1995, 1997-2000, 20032006, 2010-2012 (Fig. 6). The years of the landslide movement were separated by years of relative stability of the landslide.

The north-western part of the A plot was most prone to landslide (Fig. 7A), where more than 10 trees (7\% of all studied trees) have recorded seven landslides activations and more (Fig. 8). The southern part of the research site was less active - only three pines $(2 \%)$ indicated a large number of mass movements. In contrast, the central-eastern part of the A plot was characterized by the highest stability.

The first traces of mass movements within the research site B, recorded in the annual growth rings of the studied trees come from the last decade of the $19^{\text {th }}$ century. The periods of landslide activity within the B plot included the years: 1900-1901, 1905, 1911, 1913, 1920-1921, 1928-1931, 1935, 1937-1938, 1941-1943, 1945-1946, 1959-1960, 1962, 1967, 1969, 1973-1974, 1976-1977, 1980-1985, 1988, 1990-1993, 1997, 2001, 2003-2004, 2006-2007, 2010-2011 (Fig. 9).

The northern part of the B plot was characterized by highest activity, while its central and southern parts were more stable (Fig. 7B). The number of trees which recorded at least 10 landslide activity events was the highest in the northern part of the landslide (Fig. 10).

\section{Eccentricity index of tree rings}

Eccentricity indexes were calculated for each tree. Silver fir trees were characterized by upslope side eccentricity - arithmetic average of the index was $4.8 \%$ (Table 2). On the other hands, the downslope side eccentricity was typical for Scots pine tree rings $(-5.7 \%)$. The arithmetic average of the eccentricity index for all studied trees amounted $-0.4 \%$. Maximal upslope side eccentricity index of $144.4 \%$ was calculated for Scots pine no. A063, located in the most southern part of research site A, on western slopes of the Szklarka valley. Minimal downslope side eccentricity index $(-350 \%)$ was measured in rings of silver fir no. A567 in the north-eastern part of research site B, on the eastern slopes of the Szklarka valley.

Table 2. The descriptive characteristics of the eccentricity index calculated for sampled trees within the Sawicki landslide

\begin{tabular}{lrrr}
\hline \multirow{2}{*}{\multicolumn{1}{c}{ Statistics }} & \multicolumn{1}{c}{$\begin{array}{c}\text { Abies } \\
\text { alba }\end{array}$} & $\begin{array}{c}\text { Pinus } \\
\text { sylvestris }\end{array}$ & \multicolumn{1}{c}{$\begin{array}{c}\text { All } \\
\text { species }\end{array}$} \\
\cline { 2 - 4 } & \multicolumn{3}{c}{$\%$} \\
\hline Minimum & -350.0 & -92.3 & -350.0 \\
Arithmetic average & 4.8 & -5.7 & -0.4 \\
Maximum & 100.0 & 144.4 & 144.4 \\
Standard deviation & 8.0 & 7.0 & 8.3 \\
\hline
\end{tabular}

\section{Influence of precipitation on the landslide activity}

The periods of landslide activity obtained on the basis of the dendrogeomorphological analysis were correlated with precipitation data. The precipitation rate was computed for the hydrological year, calculated from $1^{\text {st }}$ of November to $31^{\text {st }}$ of October. Wet years were distinguished as those in which the annual sum of rainfall exceeded $900 \mathrm{~mm}$ (Fig. 11). Wet years were assigned to: 1970, 1974, 1980, 1983, 1985, 1998, 2001, 2009-2011. Annual rainfall, however, may not always be reflected in a geomorphic activity, such as landslide movements. In the dormant seasons the amount of rainfall is low and has a smaller contribution to the total annual precipitation. Previous studies conducted within the landslides in Szymbark area (Gil, Kotarba 1977, Gil, Starkel 1979, Gil 1997), as well and personal observations revealed high impact of heavy snowfalls on the activation of landslide processes. There was no correlation between designated periods of landslide activity and the total number of rainy days in different seasons (Fig. 12).

In order to investigate the rainfall events before 1968, which could have substantial effects on the activation of landslide features, the results of Twardosz and Cebulska (2014) were used. Based on rainfall data from different weather stations operating in the Carpathians, the authors have designated months of abnormally high monthly precipitation. The weather stations selected for the precipitation analysis were located average $34 \mathrm{~km}$ from Szymbark (Fig. 13). The closest weather station is located in Krynica-Zdrój $(26 \mathrm{~km})$, while the farthest station is situated in Dukla (45 km from Szymbark). Month of abnormally high precipitation for selected weather stations occurred in periods: 1897-99, 1911-13, 1936-40, 194548, 1970-74, 1980-82, 2000-01, 2004-10 (Fig. 14).

Gil and Długosz (2006) reported that landslides occur in areas with favourable geological structure such as Carpathian flysch, which fully saturated is prone to the landslide activity. In the case of the Carpathians it was assessed that amount of a long-term, continuous rainfall of $160 \mathrm{~mm}$ and more might result in landslide triggering (Słupik 1973).

On the basis of dendrochronological studies, significant correlation was observed between landslide movements and precipitation:

- In the growing season of the years 1913, 1931, $1960,1970,1972,1980,1985,1989,1997,1998$, 2001, 2006, 2007, 2010.

- In the dormant season of the years: 1911, 1955, 1976, 1977.

In the years: $1920,1935,1937,1941,1973,1975$, 1981, 1983, 1990 and 2004 traces of landslide activity were distinguished in the tree rings with a one-year delay in relation to the years with high rainfall. 

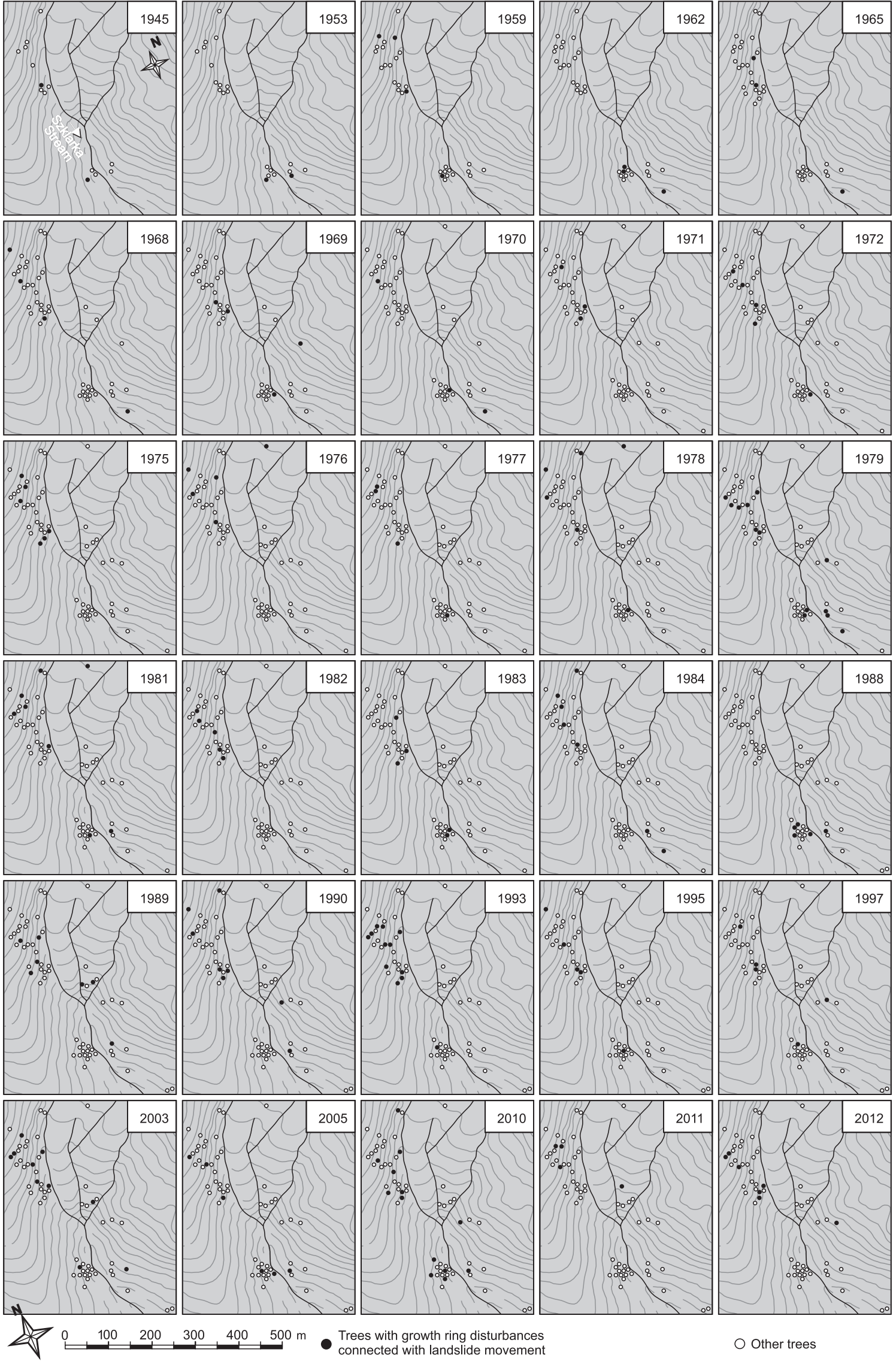

O Other trees

Fig. 6. The frequency of landslide activity events in different years within research site A, located in the southern part of the Sawicki landslide in Beskid Niski Mts 


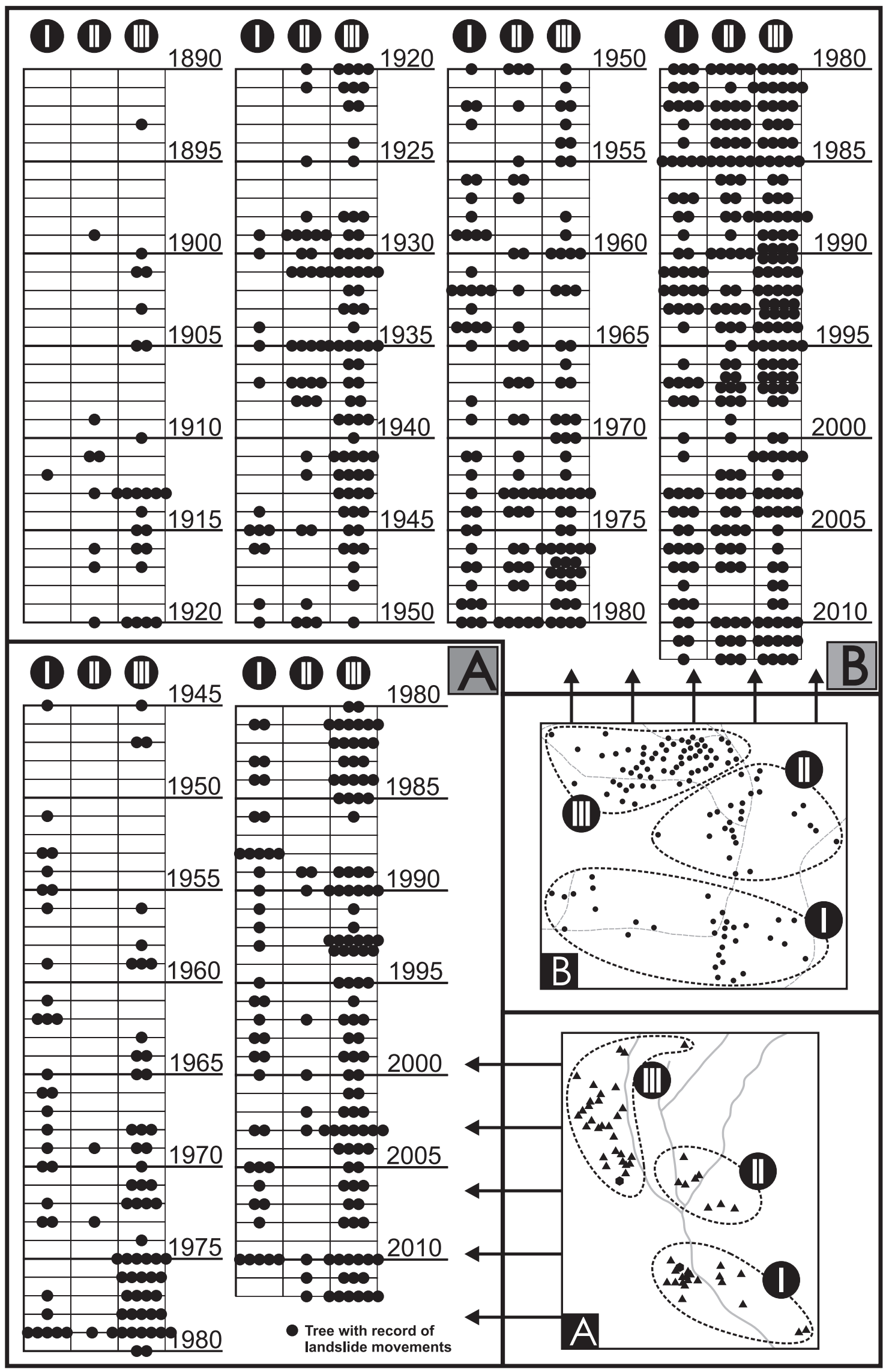

Fig. 7. The number of landslide activity events registered in the growth rings of Scots pine and silver fir tree species within different parts of research site A and B, located within the Sawicki landslide in Beskid Niski Mts 


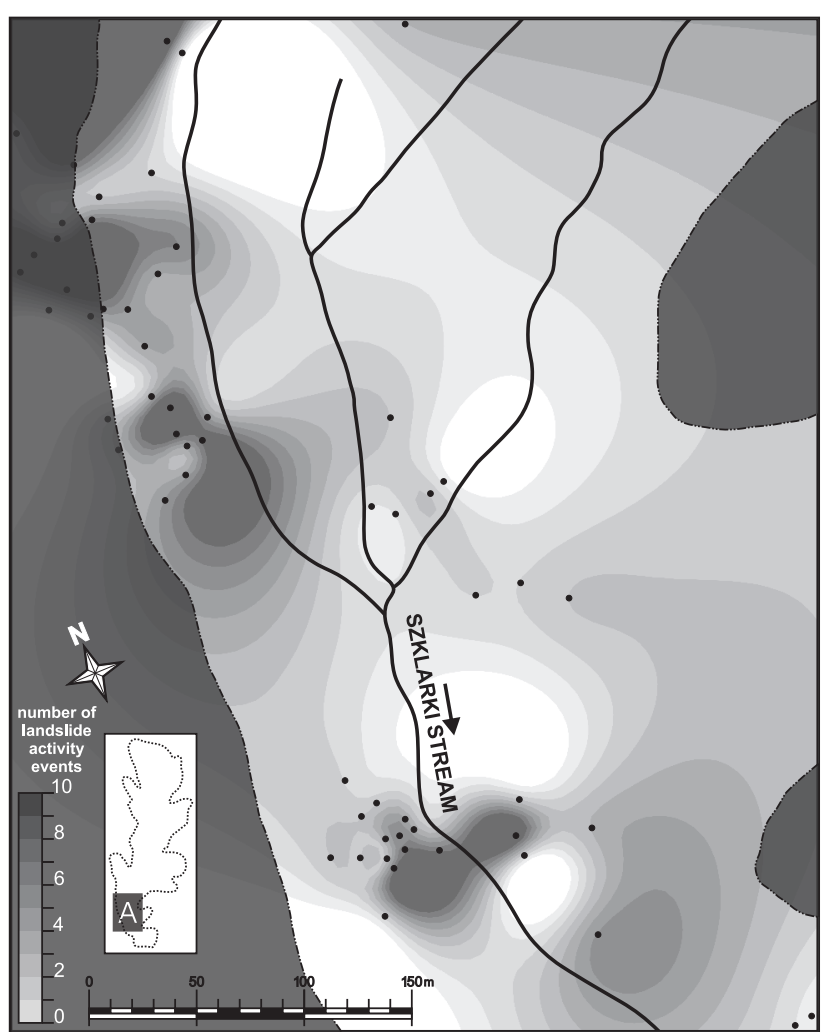

Fig. 8. Spatial variation of the landslide activity within the research site A (Radial Basis Function interpolation)

\section{Discussion}

Dendrogeomorphological studies performed in the frame of this study have been compared with previous studies conducted in the study area by means of dendrochronological tools. Krąpiec et al. (2004) determined the landslide activity periods for the following years: 1951-1953, 1965, 1971, 1973, 1977, 1981, 1986, 1988-1989, 1996-1997, 2000-2002 (Fig. 15). According to Nawrocka (2013) the landslide movements activity were recorded in the years: 1900, 1968, 1975, 1977-1979, 1983, 1988-1989, 1985, 1997-1998 (Fig. 15). In both studies there was a lack of the records for episodes that occurred earlier than those in the 50 s of the $20^{\text {th }}$ century (except the landslide event recorded in 1900). This is probably due to insufficient number of sampled trees older than 60 years collected in the previous studies (Nawrocka 2013). Since 1965, activity of landslide movements has been observed and recorded by all researchers (Krąpiec et al. 2004, Nawrocka 2013) and also by Author. The results presented in this study are similar to the results of Nawrocka (2013), especially for the following periods: 18991901, 1977-1979, 1983-1985, 1997-1998. This may be associated with the fact that the same method of dendrochronological dating was used in those studies, including assessment of annual variation of the eccentricity index. In contrast, landslide movements dated by Krąpiec et al. (2004) are in accordance with the dendrochronological record of Nawrocka (2013) and Kiszka (2016) for the periods from 1977 to 1981,1988 to 1989 . Specifically, for the year 1977 and 1997. All of the studies conducted within the Sawicki landslide demonstrated activation landslide movements recorded in the tree rings. It should be borne in mind that each study conducted within the Sawicki landslide was performed in different parts of the landslide, thus are characterized by diverse landslide activity periods established for the study area.

The resulting periods of landslide activity, obtained in this study were characterized by only partial reliance on the annual precipitation at the Research Station in Szymbark. Based on dendrogeomorphological research, the activity of landslides in wet years of 1970, 1985 and 2010 have been found. However, there was no evidence of landslide movements in a wet year 1974, while in 1980 and 1983 an offset of a one year was found in the affected trees. This delay could be due to the fact that the cambial cells are formed only during the growing season, i.e., spring and summer (Zielski, Krapiec 2004, Rossi et al. 2006). The analysis of the precipitation data in semi-annual and quarterly periods proved a possible impact of high winter precipitation on landslide activity in 1976 and 1977. The acquisition of an abnormally high monthly precipitation data (Twardosz, Cebulska 2014) made it possible to compare the precipitation conditions with periods of landslide activity in the first half of $20^{\text {th }}$ century. Following years of a possible rainfall impact on the Sawicki landslide activity were noted: in the growing season of 1913, 1931, 1960, and in the dormant season of 1911, 1955. The offset of one-year in eccentricity of tree rings was found for 1920, 1935, 1937 and 1941.

Analyzing the arithmetic average of eccentricity index between the tree species, clear division was observed. Growth rings of a Scots pine were characterized by downslope side eccentricity, whereas in the silver fir trees upslope side eccentricity was observed. It is related to the position of the studied species of trees within the landslide. Scots pine trees were located in southern part of the studied landslide, which was characterized by low altitude and close proximity to the Szklarka stream. Trees of silver fir were situated much higher, within the eastern slopes of the valley, just below the side ridge of massif. Similar results were observed by Krąpiec and Margielewski (2000), who pointed out different directions of tree trunks inclination depending in what part of the landslide they grew. Trees from landslide niche and landslide packages were the most inclined towards to the downslope side, while trees from the highest part of the landslide, i.e. growing above the main scarp, were inclined up- 
slope. Eccentricity of the rings was directly related to the direction of the tree inclination. The values of the eccentricity index revealed in this study have shown that growth rings of firs and pines had an upslope side and a downslope side eccentricity. This is mainly due to the complex morphology of the landslide. For example, above the side scarp most of silver fir trees were inclined upslope side, however, several trees within the crevices and steep packages were characterized by a reverse position. The val-
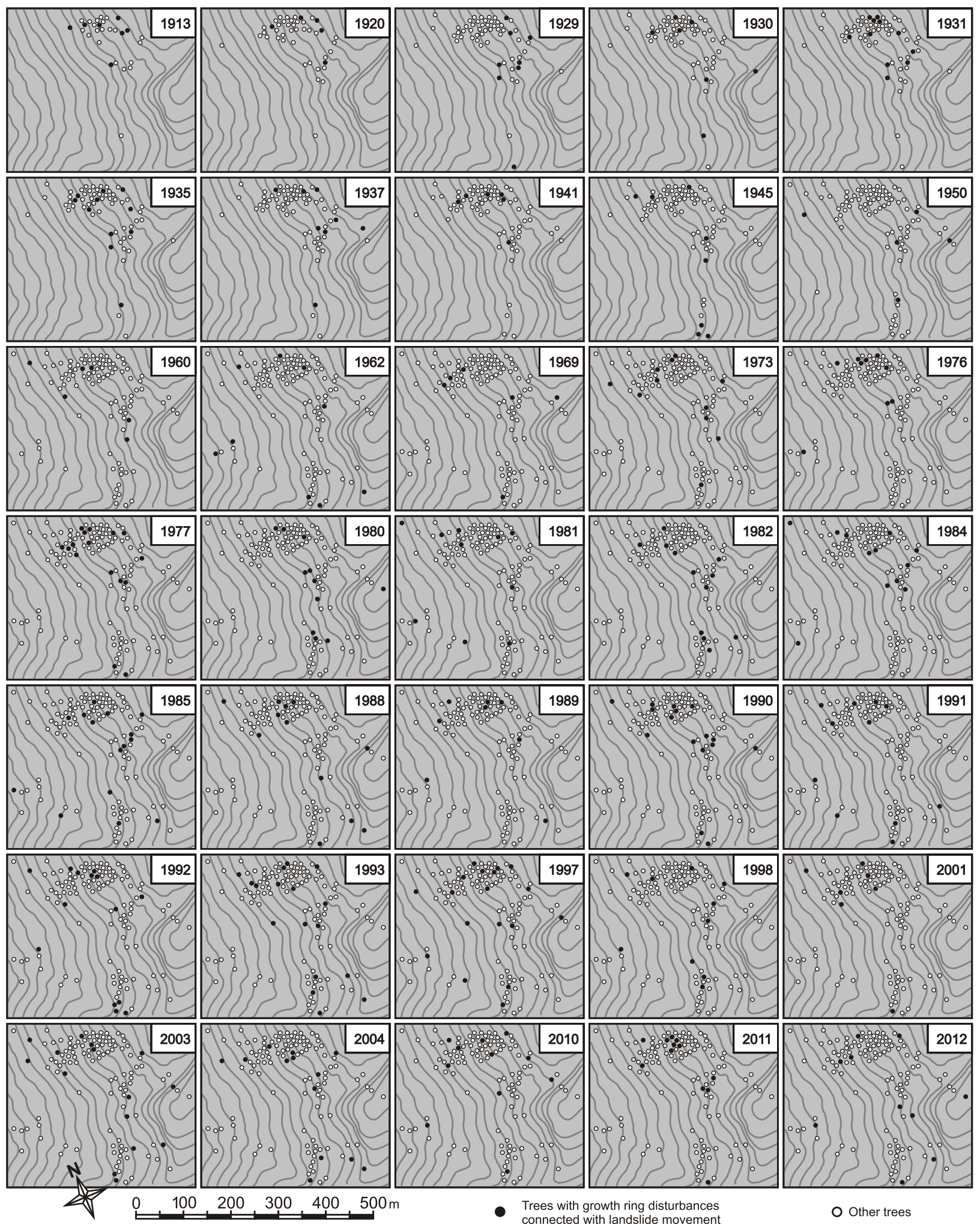

connected with landslide movement

Other trees

Fig. 9. The frequency of landslide activity events in different years within research site B, located in the southern part of the Sawicki landslide in Beskid Niski Mts 


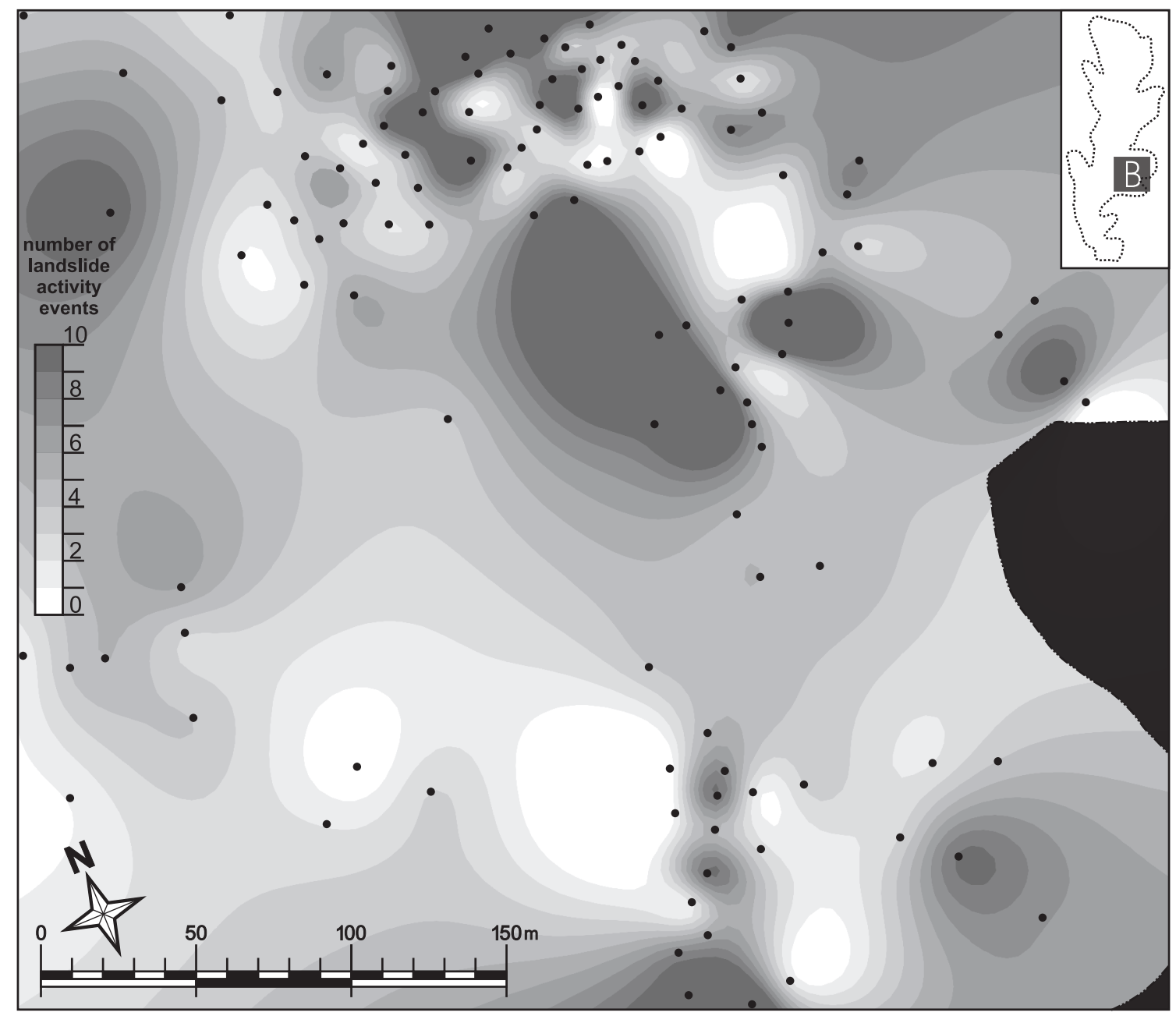

Fig. 10. Spatial variation of the landslide activity within the research site B (Radial Basis Function interpolation)

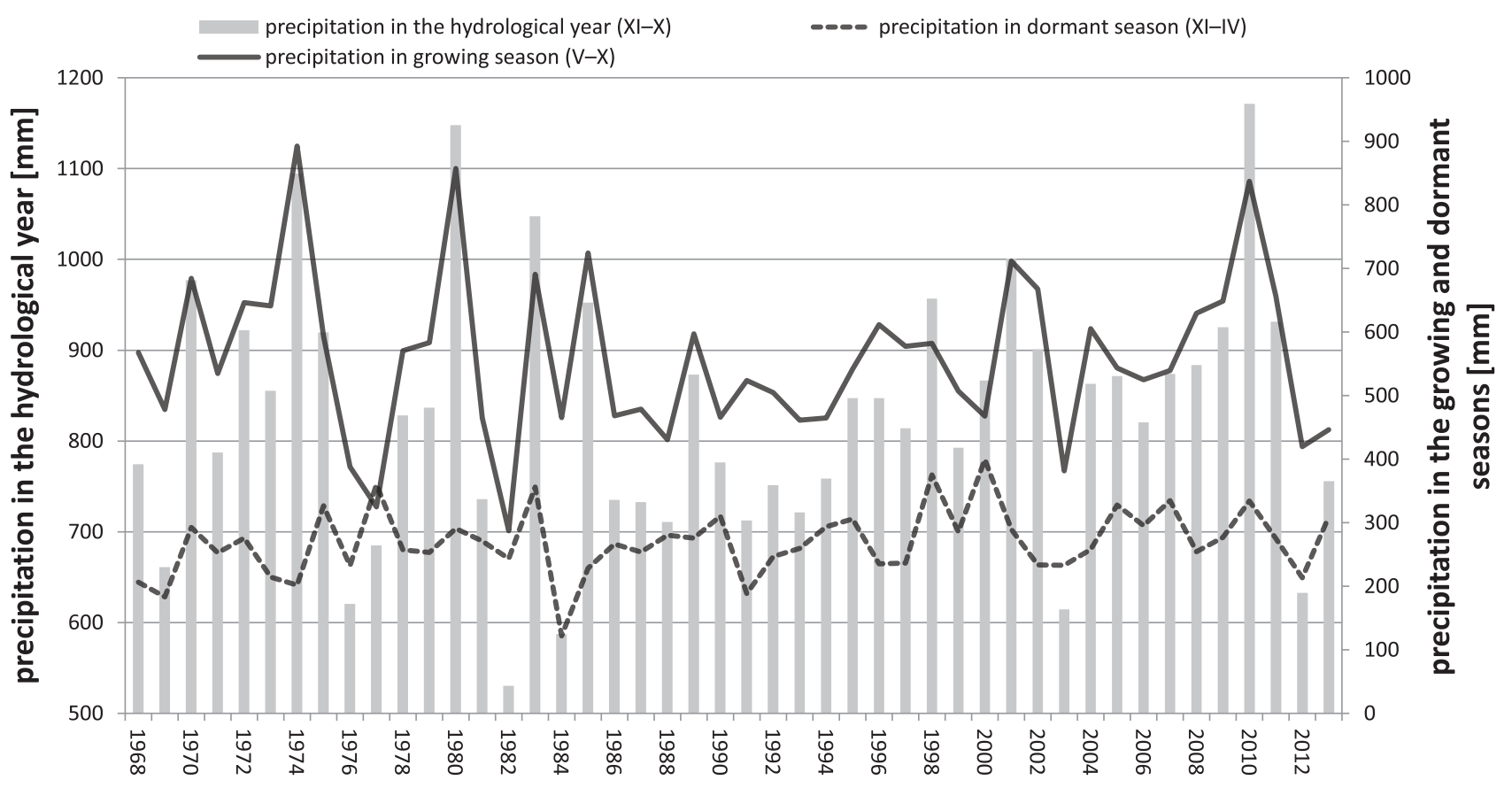

Fig. 11. Annual precipitation recorded in growing and dormant season for the period1968-2013 (source: Institute of Geography and Spatial Organization, Polish Academy of Science, Research Station in Szymbark) 


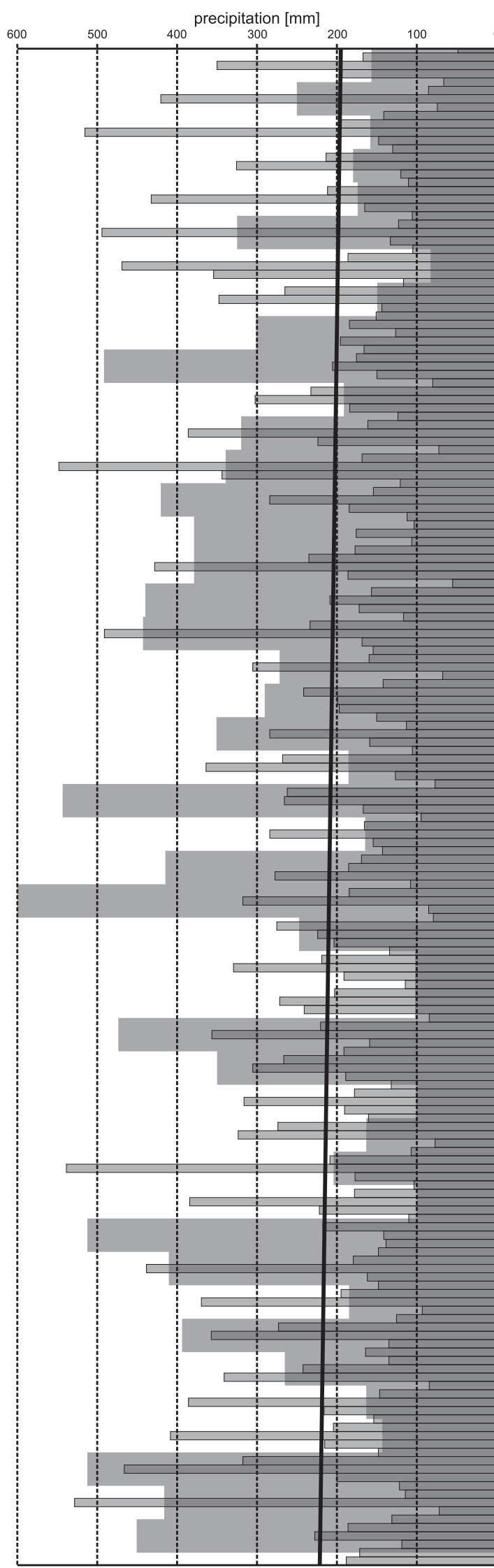

the percentage of trees with growth ring disturbances

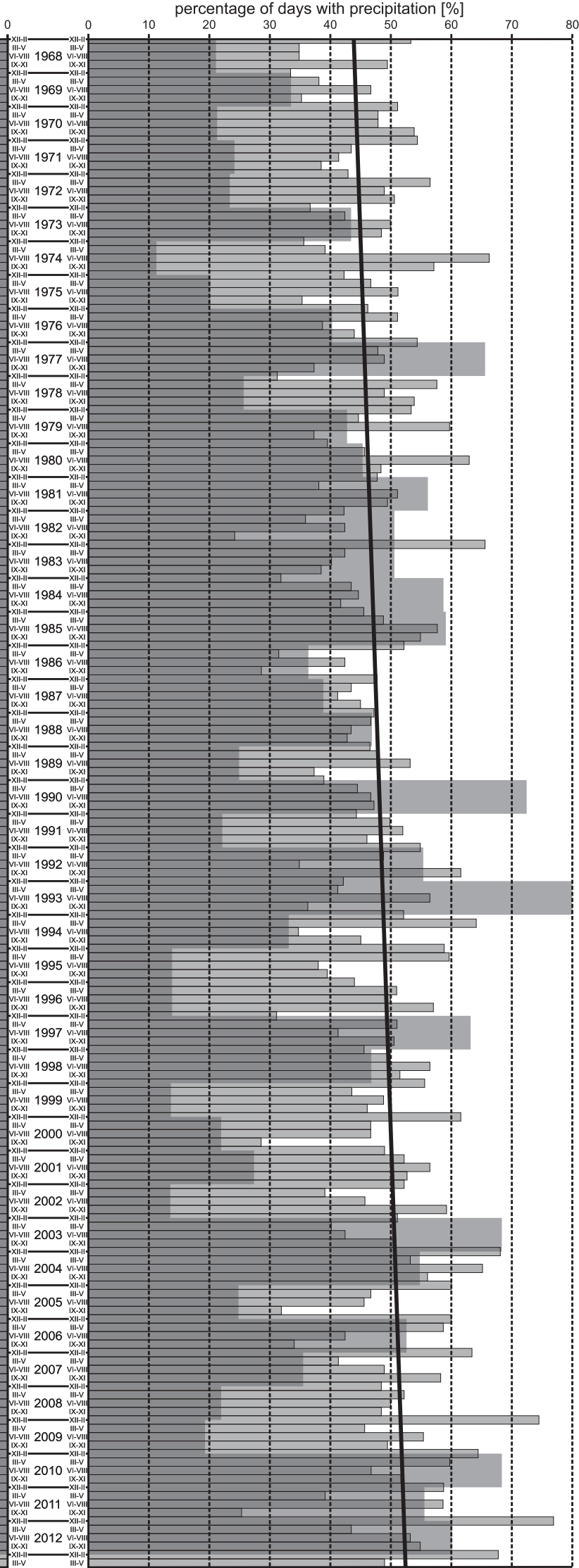

the percentage of trees with growth ring disturbances

Fig. 12. Seasonal precipitation rates for the period 1968-2013 in Szymbark area (source: Institute of Geography and Spatial Organization, Polish Academy of Science, Research Station in Szymbark) 


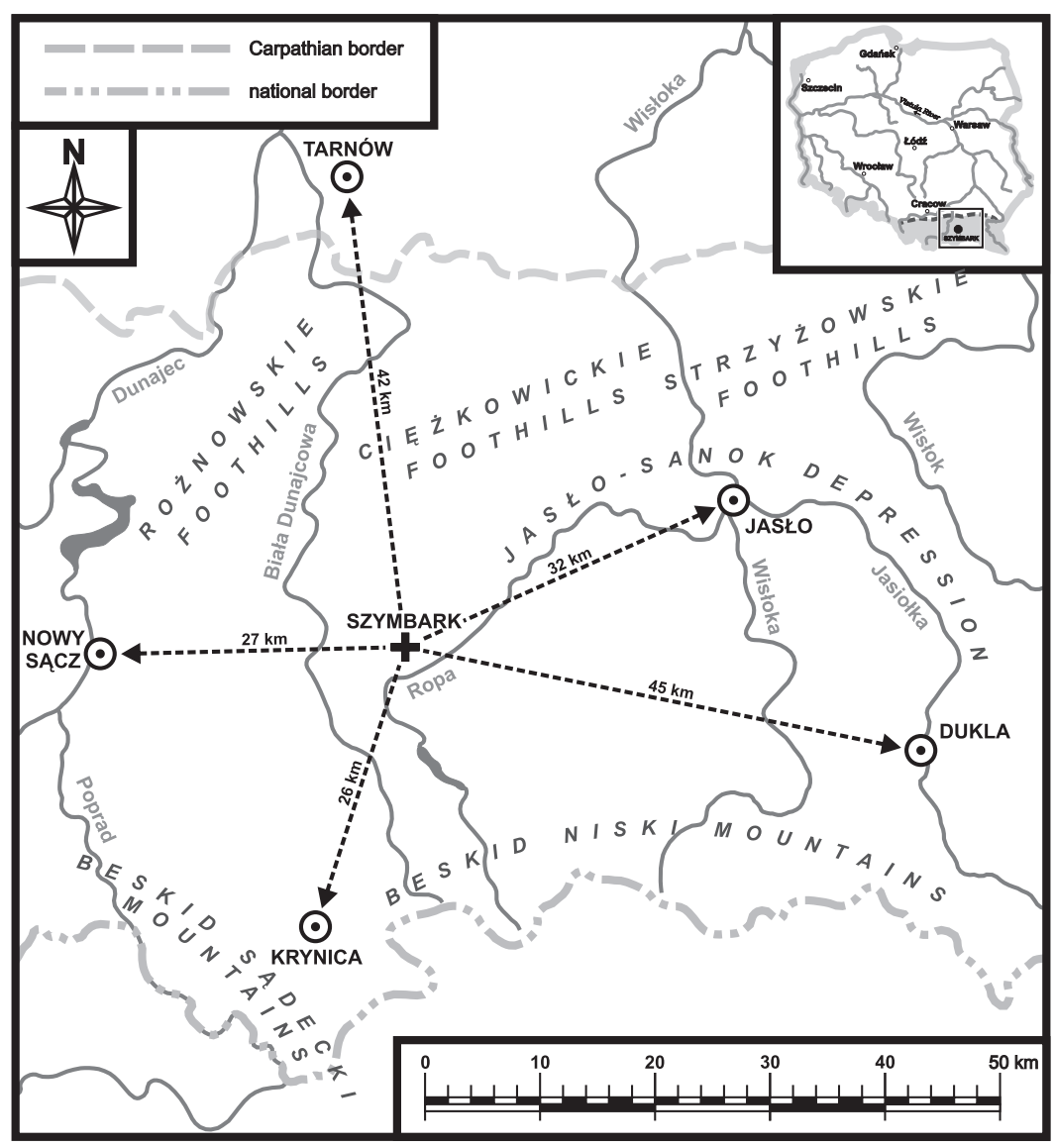

Fig. 13. Location of meteorological stations in the vicinity of the Institute of Geography and Spatial Organization, Polish Academy of Science, Research Station in Szymbark

ue of eccentricity index also might possibly depend on other elements, such as exposure, temperature, precipitation, wind, light, elevation, growing period length and soil properties (Shroder 1975, Winchester et al. 2007, Wistuba et al. 2013, Kaczka et al. 2015).

During the research it was noted that Scots pine and silver fir are species that differ with, among others: the hardness of wood, growth rate (which directly translates to their annual tree rings), the altitude at which they grow, wood anatomy, shape of stem and upper branches of a tree (i.e., Scots pines growing on landslides are often curved and crooked, whereas most of silver fir trees grow straight).

The trees of silver fir are very useful for the dendrogeomorphological research. Mostly they grow upright within the studied landslide and they produce narrow annual rings, which are more distinct and more suitable for eccentricity index analysis. However, silver firs have also some drawbacks; namely from all of coniferous trees growing in the Beskid Niski, fir wood is the hardest. During coring procedure in the field it was noted that fir wood crumbles and breaks more often than pine, spruce or larch.
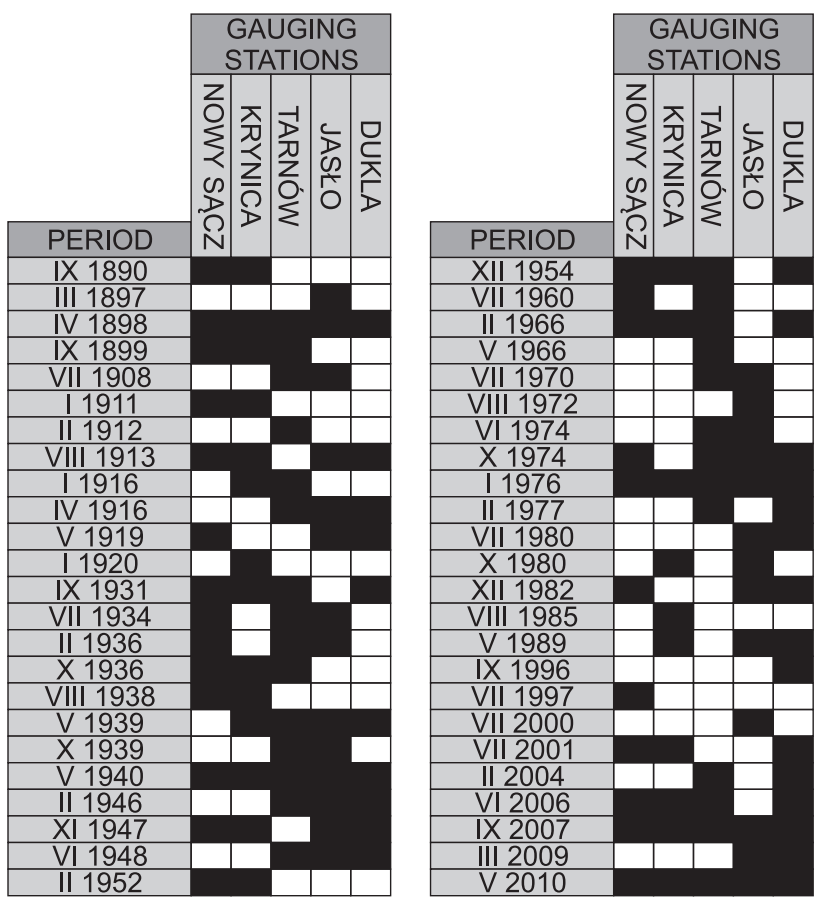

Fig. 14. Anomalously high monthly precipitation for selected periods recorded in the meteorological stations in the vicinity of the Institute of Geography and Spatial Organization, Polish Academy of Science, Research Station in Szymbark (Twardosz, Cebulska 2014) 

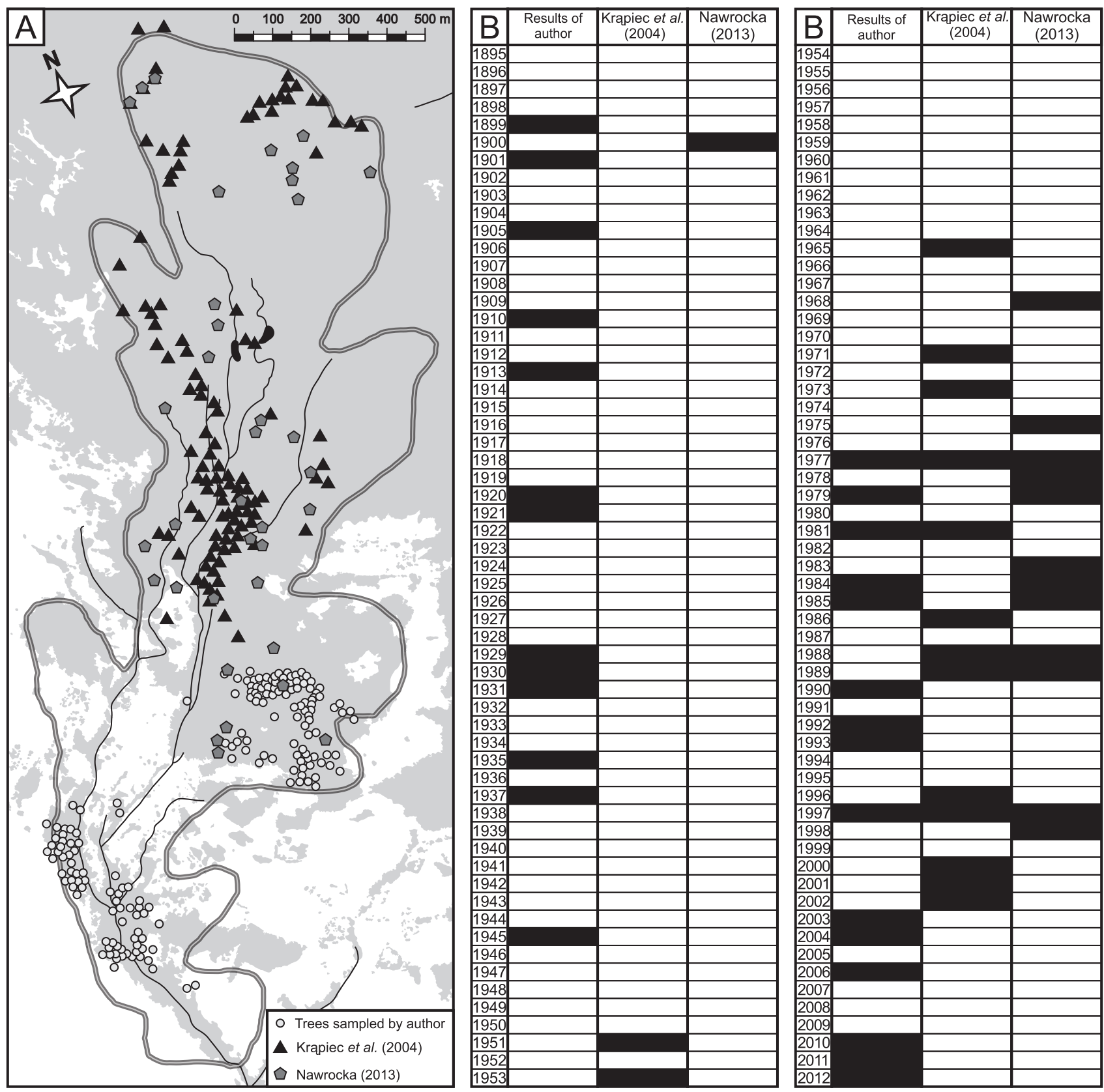

Fig. 15. The distribution of studied trees within the Sawicki landslide conducted by various researchers (A) and the frequency of landslide activity events dated through dendrogeomorphological methods across various researchers (B)

\section{Conclusions}

The dendrogeomorphological method allowed to determine the spatial variability of a landslide activity. Specifically, the results of the study have shown that the highest landslide activity was characterized for the northern part of the research site B and the south-western slopes of the Szklarka stream valley (site A). The main limitation of this method is the possibility to use only in the forest area. The time span of the landslide activity reconstruction was limited by the age of studied trees. Silver firs were the oldest trees reaching up to 20 years. The age of the oldest silver firs made it possible to determine the Sawicki landslide activity for the early twentieth century.

Analysis of annual variation of the eccentricity index, calculated for Scots pine and silver fir, revealed the years with the greatest landslide activity in: 1899, 1901, 1905, 1910, 1913-1914, 1920-1921, 1929-1931, 1935, 1937, 1945, 1977, 1979, 1981, 1984-1985, 1990, 1992-1993, 1997, 2003-2004, 2006, 2010-2012. The period 1890-2012 was divided into three cycles of varying intensity of mass movements: period 1885 - 1945 with many landslide episodes, period 1946 1976 with little landslides activity, and the third period (1977-2012) with the largest number of landslide 
events. The periods of the Sawicki landslide activity obtained in this study are similar to results achieved by Krąpiec et al. (2004) and Nawrocka (2013) for the northern and central part of the study area.

The eccentricity index values established for the Sawicki landslide ranged from $-350 \%$ to $100 \%$ for the silver fir and from -92.3 to 144.4 for the Scots pine. Mean values of the index indicated the positive eccentricity of Abies alba and negative eccentricity for Pinus sylvestris. It was dependent on the position within the landslide and the inclination of the tree trunks analysed. Studies have shown only a partial dependence between precipitation sums and landslide episodes, which are more commonly occurring during the growing seasons.

The differences in the growth reaction between two studied coniferous tree species under the landslide movements influence were revealed. Silver fir (Abies alba) has greater application than the Scots pine (Pinus sylvestris), but it's sampling is more challenging due to larger hardness and brittleness of the wood.

\section{Acknowledgement}

I would like to express my deepest appreciation to two anonymous reviewers who provided me the possibility to improve and complete this paper.

\section{References}

Alestalo J., 1971. Dendrochronological interpretation of geomorphic processes. Fennia 105: 1-140.

Ballesteros-Cánovas J.A., Stoffel M., Guardiola Albert C., Díez Herrero A., 2015. XRCT imagery and variograms reveal 3D changes in wood density of riparian trees affected by floods. Trees - Structure and Function 29: 1115-1126.

Bednarz Z., 1986. An example of the application of the tree-ring chronology of the Dwarf Mountain Pine (Pinus Mugo var Mughus Zenari) for the dating of geomorphological processes in the Tatra Mts. Dendrochronologia 4: 75-77.

Bollschweiler M., Stoffel M., Vázquez-Selem L., Palacios D., 2010. Tree-ring reconstruction of past lahar activity at Popocatépetl, Mexico. The Holocene 20: 265-274.

Buchwał A., Wrońska-Wałach D., 2008. Zapis denudacji naturalnej $\mathrm{i}$ antropogenicznej $\mathrm{w}$ odsłoniętych korzeniach świerka (Picea abies) (Karpaty fliszowe). Landform Analysis 11: 71-76.

Butler, D.R., 1979. Dendrogeomorphological analysis of flooding and mass movement, Ram Plateau,Mackenzie Mountains, Northwest Territories. The Canadian Geographer 23: 62-65.

Chowaniec J., Wójcik A., Mrozek T., Raczzkowski W., Nescieruk P., Perski Z., Wojciechowski T., Marciniec P., Zimnal Z., Granoszewski W., 2012: Osuwiska w województwie małopolskim. Atlas - przewodnik. Departament Środowiska, Rolnictwa i Geodezji Urzędu Marszałkowskiego Województwa Małopolskiego, Zespół Geologii, pp. 143.

Fantucci R., McCord A., 1995. Reconstruction of landslide dynamic with dendrochronological methods. Dendrochronologia 13: 33-48.

Franco-Ramos O., Stoffel M., Vazquez-Selem L., Capra L., 2013. Spatio-temporal reconstruction of lahars on the southern slopes of Colima Volcano, Mexico - a dendrogeomorphic approach. Journal of Volcanology and Geothermal Research 267: 30-38.

Gil E., 1979. Typologia i ocena środowiska przyrodniczego okolic Szymbarku. Dokumentacja Geograficzna 5: 1-91.

Gil E., 1994. Szata roślinna. [In:] L. Starkel, E. Gil (red.), Zintegrowany Monitoring Środowiska Przyrodniczego, Stacja Bazowa Szymbark (Karpaty Fliszowe), Biblioteka Monitoringu Środowiska: $44-47$.

Gil E., 1997. Meteorological and hydrological conditions of landslides in the Polish Flysch Carpathians. Studia Geomorphologica Carpatho-Balcanica 31: 143-158.

Gil E., Kotarba A., 1977. Model of slide slope evolution in flysch mountains (An example drawn from the Polish Carpathians). Catena 4(3): 233-248.

Gil E., Starkel L., 1979. Long-term extreme rainfalls and their role in the modelling of flysch slopes. Studia Geomorphologica Carpatho-Balcanica 13: 207-120.

Gil E., Długosz M., 2006. Threshold values of rainfalls triggering selected deep-seted landslide in the Polish Flysch Carpathians. Studia Geomorphologica Carpatho-Balcanica 40: 21-43.

Kaczka R., Karolina Janecka K., Lempa M., Rączkowska Z., 2015. Zastosowanie metod dendrochronologicznych w badaniach lawin śnieżnych. Landform Analysis 28: 15-27.

Krąpiec M., Margielewski W., 2000. Analiza dendrogeomorfologiczna ruchów masowych na obszarze polskich Karpat fliszowych. Kwartalnik AGH, Geologia 26(2): 141-171.

Krąpiec M., Rączkowski W., Gil E., Kłusek M., Janicki T., Kowalski Z., Zabuski L., 2004. Zastosowanie analizy dendrogeomorfologicznej do monitoringu obszarów osuwiskowych w Beskidzie Niskim oraz jego praktyczne wykorzystanie. Grant badawczy nr KBT 4T12B 02526.

Krąpiec M., Rączkowski W., Danek M., Gil E., Kłusek M., Zabuski L., 2008. Monitoring dendrogeomorfologiczny osuwisk w Beskidzie Niskim. Prace Komisji Paleogeografii Czwartorzędu Polskiej Akademii Umiejętności 6: 173-184.

Lopez Saez J., Corona C., Stoffel M., Berger F., 2014. Assessment of forested shallow landslide movements coupling tree ring records from stems and exposed roots. Géomorphologie: relief, processus, environnement 2: 159-174.

Malik I., 2008. Dating of small gullies formation and rates of erosion in old gullies under forest by means of anatomical changes in exposed tree roots (Southern Poland), Geomorphology 93: 421-436.

Malik I., Owczarek P., 2005. Wykorzystanie odsłoniętych korzeni drzew do określenia przebiegu erozji zboczy dolin i dostawy zwietrzelin do koryt rzek górskich (Sudety Wschodnie), Czasopismo Geograficzne 76: 101-116.

Malik I., Matyja M., 2008. Bank erosion history on a mountain stream determined by means of anatomical changes in exposed tree roots over the last 100 years (Bílá Opava River - Czech Republic). Geomorphology 98: 126-142.

Malik I., Owczarek P., 2009. Dendrochronological records of debris flow and avalanche activity in a mid - mountain forest zone (eastern Sudetes - central Europe). Geochronometria 34: $57-66$.

Margielewski W., 1997. Dated landslides of the Jaworzyna Krynicka Range (Polish Outer Carpathians) and their relation to climatic phases of the Holocene. Annales Societatis Geologorum Poloniae 67: 83-92.

Margielewski W., 1998. Landslide phases in the Polish Outer Carpathians and their relation to the climatic changes in the Late Glacial and the Holocene. Quaternary Studies in Poland 15: 37-53.

Migoń P., Kacprzak A., Malik I., Kasprzak M., Owczarek P., Wistuba M., Panek T., 2014. Geomorphological, pedological and dendrochronological signatures of a relict landslide terrain, Mt Garbatka (Kamienne Mts), SW Poland. Geomorphology 219: 213-231.

Nawrocka N., 2013. Analiza dendrogeomorfologiczne drzew różnych gatunków z obszaru osuwiska „L. Sawickiego” w Szymbarku, Beskid Niski, Karpaty Zewnętrzne. Folia Quaternaria 81: 175-188. 
Rączkowski W., 2004. Landslide Hazard in the Carpathians during the recent 10 years. Global Change 10: 67-76.

Rączkowski W., Zabuski L., 2008. Numeryczne Modelowanie deformacji stoku osuwiskowego - Maślana Góra w Szymbarku k. Gorlic. Kwartalnik Akademii Górniczo-Hutniczej, Geologia 34(4): 733-742.

Rossi S., Deslauriers A., Anfodillo T., 2006. Assessment of cambial activity and xylogenesis by microsampling tree species: an example at the Alpine timberline. IAWA Journal 27: 383-394.

Sawicki L., 1917. Osuwiska ziemne w Szymbarku i inne zsuwy powstałe w r. 1913 w Galicji zachodniej. Rozprawy Wydz. Mat. Przyr. PAU 3(13A): 227-313.

Słupik J., 1973. Zróżnicowanie spływu powierzchniowego na fliszowych stokach górskich, Dokumentacja Geograficzna 2: $1-118$.

Schweingruber F. H., 1996. Tree-Rings and Environment. Dendroecology. Swiss Federal Institute for Forest, Snow and Landscape Research. Vienna. 609 pp.

Shroder J.F.,1975. Dendrogeomorphological analysis of mass movement. Proceedings of the Association of American Geographers 7: 222-226.

Shroder J.F., 1980. Dendrogeomorphological analysis of mass movement on Table Cliffs Plateau Utah. Quaternary Research 9: 168-185.

Šilhán K., 2012. Dendrogeomorphological analysis of the evolution of slope processes on flysch rocks (Vsetínské vrchy Mts; Czech Republic). Carpathian Journal of Earth and Environmental Sciences 7: 39-49.

Šilhán K., 2016. How different are the results acquired from mathematical and subjective methods in dendrogeomorphology? Insights from landslide movements. Geomorphology 253: 189-198.

Šilhán K., Pánek T., Hradecký J., Stoffel M., 2015. Tree-age control on reconstructed debris-flow frequencies: examples from a regional dendrogeomorphic reconstruction in the Crimean Mountains. Earth Surface Processes and Landforms 40: 243-251.

Stoffel M., Perret S., 2006. Reconstructing past rockfall activity with tree rings: Some methodological consideration. Dendrochronologia 24: 1-15.
Szychowska-Krąpiec E., 2000, Późnoholoceński standard dendrochronologiczny dla jodły Abies alba Mill. z obszaru południowej Polski. Kwartalnik AGH, Geologia 26: 173-299.

Twardosz R., Cebulska M., 2014. Anomalnie wysokie miesięczne opady atmosferyczne w Polskich Karpatach i na ich przedpolu (1881-2010). Prace Geograficzne 138: 7-28.

Winchester V., Gartner H., Bezzi M., 2007. Dendrogeomorphological applications. [In:] Kalvoda, J., Goudie, A.S. (eds), Geomorphological Variations. Prague: 183-203.

Wistuba M., 2008. Dendrochronologiczne wskaźniki fluwialnej erozji i depozycji w ujściowych odcinkach dopływów Èernej Opavy (Hrubý Jeseník, Sudety Wschodnie). Landform Analysis 9: 394-397.

Wistuba M., Malik I., 2011. Indeks dekoncentryczności przyrostów rocznych drzew - narzędzie do identyfikacji współczesnych ruchów osuwiskowych. Czasopismo Geograficzne 82(4): 401-421.

Wistuba M., Malik I., Gärtner H., Kojs P., Krąpiec M., 2012. Zastosowanie dekoncentryczności przyrostów rocznych świerka pospolitego (Picea abies Karst.) w analizie dynamiki osuwiska - przykład z masywu Hrubégo Jeseníka (Sudety Wschodnie). Studia i Materiały CEPL w Rogowie 14, 1(30): 185-194.

Wistuba M., Malik I., Gärtner H., Kojs P., Owczarek P., 2013. Application of eccentric growth of tree-rings as a tool for landslide analyses (an example of Picea abies Karst. in the Carpathian and Sudeten Mountains - Central Europe). Catena 111: 41-55.

Wojciechowski T., Marciniec P., Zimnal Z., Granoszewski W., 2012. Osuwiska w województwie małopolskim. Atlas - przewodnik. J. Chowaniec, A. Wójcik (red.), Departament Środowiska, Rolnictwa i Geodezji Urzędu Marszałkowskiego Województwa Małopolskiego, Zespół Geologii: 1-143.

Zielonka T., Dubaj N., 2009. A tree-ring reconstruction of geomorphologic disturbances in cliff forests in the Tatra Mts. Landform Analysis 11: 71-76.

Zielski A., Krąpiec M., 2004. Dendrochronologia. PWN, Warszawa. 